\title{
A co-authorship network analysis of national and international growth in prehistoric archaeology, Italy (1875-2000)
}

\section{Combining bibliometric and qualitative data in history of science research}

\author{
Sébastien PlutniaK*
}

S. Plutniak, École française de Rome, Lisst-Cers UMR 5193, sebastien.plutniak@ehess.fr

This paper examines the national and international growth of prehistoric archaeology in Italy from 1875 to 2000 . A bibliometric approach is proposed for a case study of a scientific discipline, language and period that are poorly represented in current bibliographic databases. These constraints led to the generation of a data set with articles from 5 journals (2842 articles and 1221 unique authors). Publication language and author nationalities were manually included in the data set. Journal internationality measures and co-authorship network analyses showed: 1) that internationalisation was not the most striking change over the study period: it was one of a number of features that journal editors addressed in their own way; 2) results confirm a change in the social organisation of scientific production in archaeology, with the emergence of co-authorship and reflect the differentiation of local research trends. This is discussed with reference to previous work on the history of prehistoric archaeology.

Internationalisation, history of archaeology, scientific journals, co-authorship, bibliometrics, network analysis

Le développement national et international de l'archéologie préhistorique en Italie à travers l'analyse des réseaux de co-autorat (18752000). Combiner données bibliométriques et données qualitatives en histoire des sciences. Une analyse bibliométrique des aspects nationaux et internationaux du développement de l'archéologie préhistorique en Italie de 1875 à 2000 est proposée, soit une discipline, une langue et une période peu couvertes dans les bases bibliographiques usuelles. Cela a conduit à créer un jeu de donnée ad hoc intégrant cinq revues (2842 articles, 1221 auteurs uniques). Les langues de publication et la nationalité des auteurs ont été pris en compte. Mesurer l'internationalité des revues et analyser le réseau de co-auteurs montre: 1) que l'internationalisation ne fut pas le fait le plus marquant de cette période, constituant une ressource - parmi d'autres - diversement employée par les éditeurs; 2) une transformation dans l'organisation sociale de la production (co-autorat) et la différenciation d'orientations locales de recherche, confortant ainsi des études antérieures sur l'histoire de l'archéologie préhistorique.

Internationalisation, histoire de l'archéologie, revues scientifiques, co-autorat, bibliométrie, analyse de réseau

\section{LIMITATIONS OF BIBLIOMETRIC STUDIES} OF THE (DE)NATIONALIZATION OF SCIENCES

As in others scientific disciplines aiming to produce a universal knowledge, prehistoric archae- ology includes an international aim. There are, however, three specific points which make it of particular interest when studying internationalisation in science. First, in general, archaeological practises are closely related to international issues, being 
a practise made by a cosmopolitan elite or being an aspect of the cultural diplomacy between states. ${ }^{1}$ Second, considering the methodological aspects of historical investigation, archaeology -and specifically archaeology written in a non-English languageis a scientific discipline that is rarely included in the main bibliographic databases (e.g. Scopus, Web of Science). This raises concerning issues when using such data as historical material. Finally, concerning the Italian case, the examination of prehistoric archaeology uncovers recent processes of disciplinarisation and professionalisation ${ }^{2}$ (compared to other disciplines, such as biology). Furthermore, these processes occurred during the fascist period (1922-1943), marked by particular changes in Italian international relations and scientific policies. Numerous historical studies have addressed the growth of prehistoric archaeology in Italy from its beginnings in the eighteenth century, and its intellectual characteristics, such as the importance of the "palethnology" idea. In addition, they have addressed the creation of organisations dedicated to the practise of prehistoric archaeology, emphasising their role in the development framework of the Italian state and in the fascist regime. ${ }^{3}$

Scientific internationalism has been an important issue since the nineteenth century, and was redefined after both World Wars in the twentieth century. ${ }^{4}$ In general, relations between national identities and institutions, and scientific practises have been studied continuously by historians and sociologists of science. ${ }^{5}$ During the last decades of the twentieth century, concepts such as "transnational" science or "glocalization" were proposed by authors in social studies of science. Subsequently, they were enthusiastically adopted by historians of archaeology. ${ }^{6}$ National frameworks for the history of science have been criticised, arguing that this approach lacks the intrinsic international features of science and deserves a narrative of national legitimization. As Crawford et al. emphasised, "denationalisation" was the main trend during the 1980s and early 1990s. These authors also argued, however, that analysing the relationships between national frameworks and scientific activities on a broader time-scale shows that: 1) trends of (de)nationalisation occurred periodically throughout the history of science; 2 ) that these processes were achieved by various methods including the emergence of spontaneous associations, state bureaucracy policies, the migration of scientists, and the creation of "locally-grounded transnational research sites". ${ }^{7}$

Such insights suggest that the main problem is not the investigation of contrasting national and international scientific practises, but the empirical examination of the various forms of (inter) nationalisation. Concerning the latter, for decades, sociologists and historians of science have used a wide range of specific data set to examine scientific activities, including: scientific production (actors' involvement in fieldwork, publication languages, patents and publications), socialisation (affiliation to institutions, participation in conferences), reception or visibility (citations). These data are used to address "internationality" in different ways, including cognitive perspectives (e.g. relationships between documents), spatial perspectives (analysing their global or national distribution), and social perspectives (e.g. co-authorship or co-presence of actors at conferences). However, as noted by Buela et al. on scientometric approaches, accounts of internationality often lack a precise definition of this concept and of the methods used for its empirical study. ${ }^{8}$ In addition, actors' understanding of internationality in science can change over time. ${ }^{9}$ Similar criticism on qualitative approaches has also been made by Heilbron about comparative studies of national traditions in science. ${ }^{10}$ On one hand, promoters of qualitative approaches are often reluctant, also for political reasons, to consider bibliometric and scientometric
1. See contributions in Delley et al. 2016.

2. On this distinction, see Gingras 1991.

3. Tarantini 2004.

4. For a historical account of universalism and internationalism values, see Somsen 2008; see also Elzinga Landström 1996.

5. Crawford - Shinn - Sörlin 1993. See Forman's classic papers about physics in the post WWI period, Forman 1971.

6. See Kaeser 2002 or, on an Italian case, Díaz-Andreu 2014.
7. Crawford - Shinn - Sörlin 1993, p. 23-27.

8. Buela-Casal et al. 2006, p. 46-47.

9. Somsen 2008.

10. Heilbron 2008 , p. 8. 
approaches. On the other hand, even if bibliometric data have been used for decades as sources for the history of science, ${ }^{11}$ these studies often lack a precise historical or sociological contextualisation of the bibliographic data under study.

To address this limitation, this paper focuses on a case (i.e. a scientific field, language, and period) that is poorly represented in the main bibliometric databases of today: namely, prehistoric archaeology in Italy from 1875 to 2000. In this framework, the relationship between bibliographic data and its socio-historical contexts can be explored. I propose an approach combining general information from bibliographic statistics and fine-grained information from qualitative data. After presenting the materials, I discuss the results starting with an examination of the growth of actors and publications related to prehistoric archaeology in Italy. Journal internationality measures are then presented and, finally, I analyse the co-authorship network of involved archaeologists from 1875 to 2000 .

\section{AN ENRICHED BIBLIOGRAPHIC DATA SET}

The data se $\mathrm{t}^{12}$ includes all the articles published in 5 journals between 1875 and 2000 (tab. 1). These journals were selected as they cover the broadest range of prehistoric archaeology studies in Italy. Some were included for specific reasons: the Bullettino di paletnologia italiana (BPI) has the widest chronological range, allowing for longterm observations; the Rivista di scienze preistoriche $($ RSP), Origini. Preistoria e protostoria delle civiltà antiche and Quaternaria. Storia naturale e culturale del Quaternario are amongst the most important prehistoric archaeology journals in Italy; and Archivio di tipologia analitica (ATA) has interesting characteristics regarding the internationalisation of science, that I detail below. The journal data set is chronologically limited to 2000 for consistency with the publication period of the ATA which ended in 1998.

As the main bibliographic databases poorly represented scientific articles in archaeology and languages other than English, ${ }^{13}$ I constructed the data set by combining information extracted from the following sources: direct examination of the journals, the PreBiblio, ${ }^{14}$ Dialnet, ${ }^{15}$ and Google Scholar databases. This information was organised into 3 tables: articles $(n=2842)$, authors $(n=1221)$, and relations between articles and authors $(n=3366)$. The languages of the articles were described manually as well as the nationality of the authors (this biographical feature has been used instead of authors' institutional affiliations which are generally used in bibliometric studies as it is easier to retrieve from databases). Nationality was known from my previous research for about half of the authors, and for the other half, it was determined through searching archaeological publications or on the internet.

TAB. 1 - Journals INCLUdEd IN THE DATA SET, WITH CITY OF PUBLICATION, FIRST AND LAST YeAR OF PUBLICATION (OR LAST YEAR INCLUDED IN THE DATA SET IF THE JOURNAL HAS CONTINUED TO BE PUBliSHED AFTER THIS DATE).

\begin{tabular}{|l|l|l|l|l|l|}
\hline Journal name & $\begin{array}{l}\text { City } \\
\text { of publication }\end{array}$ & $\begin{array}{l}\text { First year } \\
\text { of publication }\end{array}$ & $\begin{array}{l}\text { Last year } \\
\text { of publication } \\
\text { included }\end{array}$ & $\begin{array}{l}\text { Number } \\
\text { of articles }\end{array}$ & $\begin{array}{l}\text { Number } \\
\text { of volumes }\end{array}$ \\
\hline BPI & Rome & 1875 & $1999-$ present & 1520 & 90 \\
\hline RSP & Florence & 1946 & $2000-$ present & 334 & 50 \\
\hline Quaternaria & Rome & 1954 & 1981 & 705 & 23 \\
\hline Origini & Rome & 1967 & $2000-$ present & 192 & 22 \\
\hline ATA & Siena & 1973 & 1998 & 91 & 2842 \\
\hline Sum & & & & & \\
\hline
\end{tabular}

11. See the pioneering work of De Solla Price 1963, Garfield - Sher - Torpie 1964 or, more recently, Gingras' study of Mersenne's, Oldenburg's and Darwin's correspondences, Gingras 2010.

12. Data are referenced as Plutniak 2018 and programming codes are available at http://dx.doi.org/10.7910/DVN/ VVW6KP.
13. For a synthesis on this issue and a bibliometric analysis of the linguistic and national coverage of the Thompson Scientific's database, see Archambault et al. 2006.

14. http://prebiblio.uniromal.it.

15. https://dialnet.unirioja.es. 


\section{GROWTH IN ITALIAN PREHISTORIC ARCHAEOLOGY ACTIVITIES}

\section{Numerical results}

The analysis of publications and of (new) authors growth rates identified two phases during the 1875-2000 period (fig. 1): a first phase from 1875 to 1946 (only documented by the BPI), and a second phase from 1950 to 2000. During both phases and for both series, growth rates are constant but they are higher during the second period. ${ }^{16}$ This reflects an increase in the number of actors (single authors) and publications during this phase. Furthermore, during the first phase, the growth rate of publications is slightly higher than the growth rate of actors but this reverses during the second phase. The number of authors by paper -namely the practise of co-authorship-increased in the second half of the twentieth century (see fig. 1, with greyscale indicating the annual proportions of the number of authors by publication). However, single authorship remained the major trend in this period (about $50 \%$ of the publications).

\section{Periodisation}

Tarantini proposed three phases in the development of prehistoric archaeology in Italy from 1925 to 1962, distinguished by the years 1935 and 1946. ${ }^{17}$ This model can be compared to the phases observed above.

Luigi Pigorini (1842-1925) was a prominent figure in Italian prehistoric research. In 1875 he created the BPI (with Gaetano Chierici and Pellegrino Strobel) and, one year later, he founded the Museo Preistorico Etnografico di Roma. His death occurred at the beginning of the fascist regime, a period in which his scientific and organisational legacy had to be transferred to other people. As a consequence, fascist-minded actors held some of the highest positions in the Museum and in the BPI. Tarantini selected 1935 as the beginning of the subsequent phase, corresponding to a change in

16. See results of linear regressions in supplementary materials.

17. Tarantini 2014. Guidi proposed a relatively similar periodization divided in the following years: 1860, 1900, 1920, 1940, 1970, 2000 (Guidi 2010).

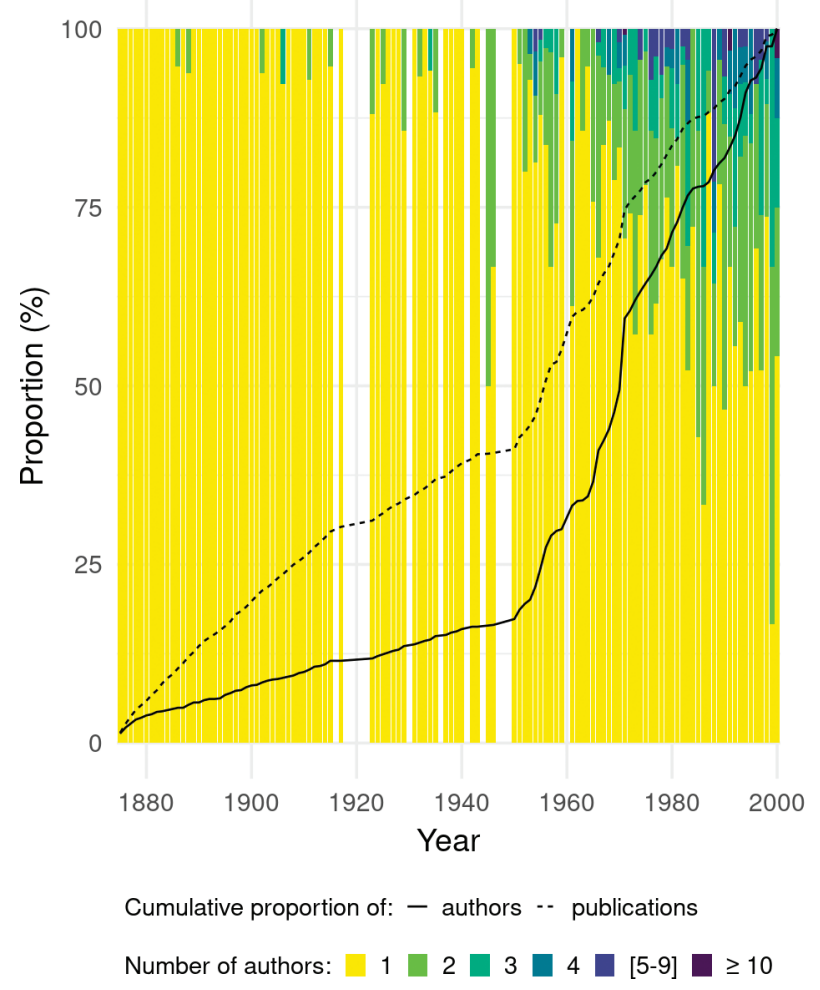

Fig. 1 - Annual proportions of the number of authors by publication in the journal data set.

The darker the area, the more co-authors in the publications.

The solid line shows the annual cumulative proportion of new authors included in the data set. The dashed line represents the annual cumulative proportion of publications. White areas represent undocumented years.

S. Plutniak.

the fascist policy towards a systematic occupation of the cultural spaces and the promotion of racism. Also in this year, Paolo Orsi, the director of the BPI, died. The journal's board was redefined, and board members were only classic archaeologists in favour of the racist orientations. ${ }^{18}$ These ideological and personal changes had no effect on the quantitative growth of actors in prehistoric archaeology or on the growth of the BPI.

In 1946, following the end of World War II and the fascist regime, a new phase in archaeology began, characterised by the creation of numerous organisations devoted to prehistoric archaeology and by the recovery of international

18. Tarantini 2004, p. 7. 
relations. In addition to the journals presented in tab. 1, it is important to mention the creation of the Centro Emiliano di Studi Preistorici in 1948, and its journal entitled Emilia Preromana, and of the Centro di Studi Preistorici e Archeologici di Varese in 1953 with its journal Sibrium. In 1950, the first Congresso Internazionale di Preistoria e Protostoria Mediterranea was held in Florence, Rome, and Naples. The observed stable growth rates reflect Tarantini's statement on the increase of activity in prehistoric archaeology during the 1946-1962 phase. The generation of researchers in the early 1960s -university-trained contrary to their predecessors- ${ }^{19}$ had an important role in the creation of journals.
(INTER)NATIONALITY AND AIMS OF JOURNALS

\section{Results}

Internationality of the journals was determined by analysing the nationalities of the authors and the languages of their articles. A total of 42 different nationalities (tab. 2) and 6 different languages (tab. 3) was observed in the full data set.

Graphic representations of the proportion of the main represented nationalities (fig. 2) and languages (fig. 3) over time are given. Although the BPI had few articles in non-Italian languages before 1950, we see that linguistic and national diversification occurred during the second half of the twentieth century, after

TAB. 2 - FREQUENCY OF ARTICLES BY JOURNAL AND BY AUTHOR NATIONALITY (ONLY THE NATIONALITIES PRESENT AT LEAST 10 TIMES ARE DETAILED).

\begin{tabular}{|l|l|l|l|l|l|l|l|}
\hline & $B P I$ & Quaternaria & $R S P$ & Origini & ATA & Sum & $\%$ \\
\hline Italian & 1411 & 468 & 433 & 230 & 110 & 2652 & 79.2 \\
\hline French & 8 & 203 & 26 & 5 & 6 & 248 & 7.4 \\
\hline USA & 1 & 125 & 4 & 5 & 0 & 135 & 4.0 \\
\hline German & 16 & 30 & 2 & 0 & 0 & 48 & 1.4 \\
\hline British & 10 & 25 & 3 & 7 & 0 & 45 & 1.3 \\
\hline Spanish & 2 & 10 & 20 & 0 & 11 & 43 & 1.3 \\
\hline Dutch & 11 & 11 & 2 & 0 & 0 & 24 & 0.7 \\
\hline Japanese & 0 & 17 & 0 & 0 & 0 & 17 & 0.5 \\
\hline Australian & 0 & 12 & 0 & 1 & 0 & 13 & 0.4 \\
\hline Russian & 0 & 10 & 3 & 0 & 0 & 13 & 0.4 \\
\hline Israeli & 1 & 6 & 3 & 0 & 0 & 10 & 0.3 \\
\hline Others & 15 & 65 & 14 & 9 & 0 & 103 & 3.1 \\
\hline Sum & 1475 & 982 & 510 & 257 & 127 & 3351 & 100 \\
\hline
\end{tabular}

The subset analysed with a $\chi^{2}$ test is indicated by italic values.

TAB. 3 - FREQUENCY OF ARTICLES By JOURNAL AND By PUbLICATION LANGUAGE.

\begin{tabular}{|l|l|l|l|l|l|l|l|}
\hline & Italian & English & French & German & Spanish & Catalan & Sum \\
\hline BPI & 1508 & 7 & 4 & 1 & 0 & 0 & 1514 \\
\hline Quaternaria & 280 & 229 & 177 & 13 & 6 & 0 & 705 \\
\hline RSP & 285 & 8 & 40 & 0 & 1 & 0 & 334 \\
\hline Origini & 166 & 23 & 2 & 1 & 0 & 0 & 192 \\
\hline ATA & 84 & 0 & 2 & 0 & 2 & 3 & 91 \\
\hline Sum & 2323 & 267 & 225 & 15 & 9 & 3 & 2842 \\
\hline
\end{tabular}

The subset analysed with a $\chi^{2}$ test is indicated by italic values. 


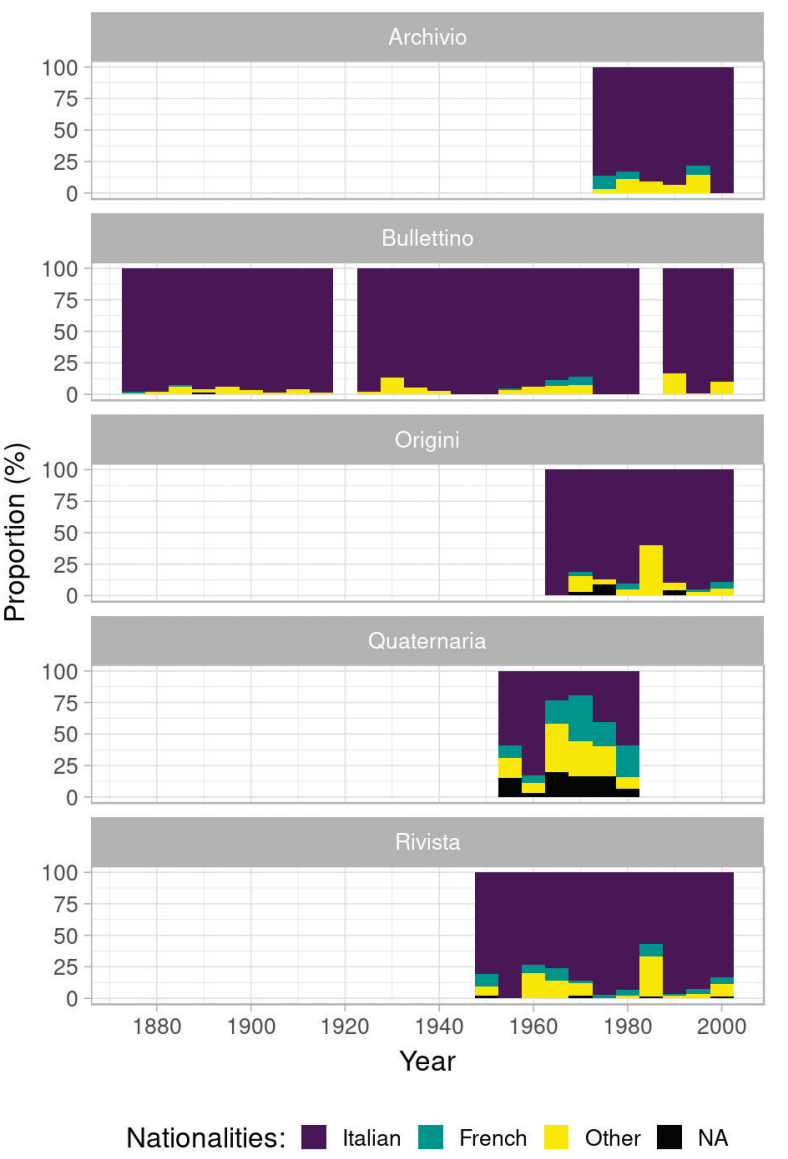

Fig. 2 - Evolution of the proportion of authors' nationalities, by journal. Each bin covers a period of five years.

S. Plutniak.

the fascist regime. For both variables (nationality and language), the general profile of each journal does not change radically over time, except for Quaternaria, whose rate of non-Italian authors increased significantly from the mid-1960s.

For a quantitative and comparative account of these evolutions the study period was divided

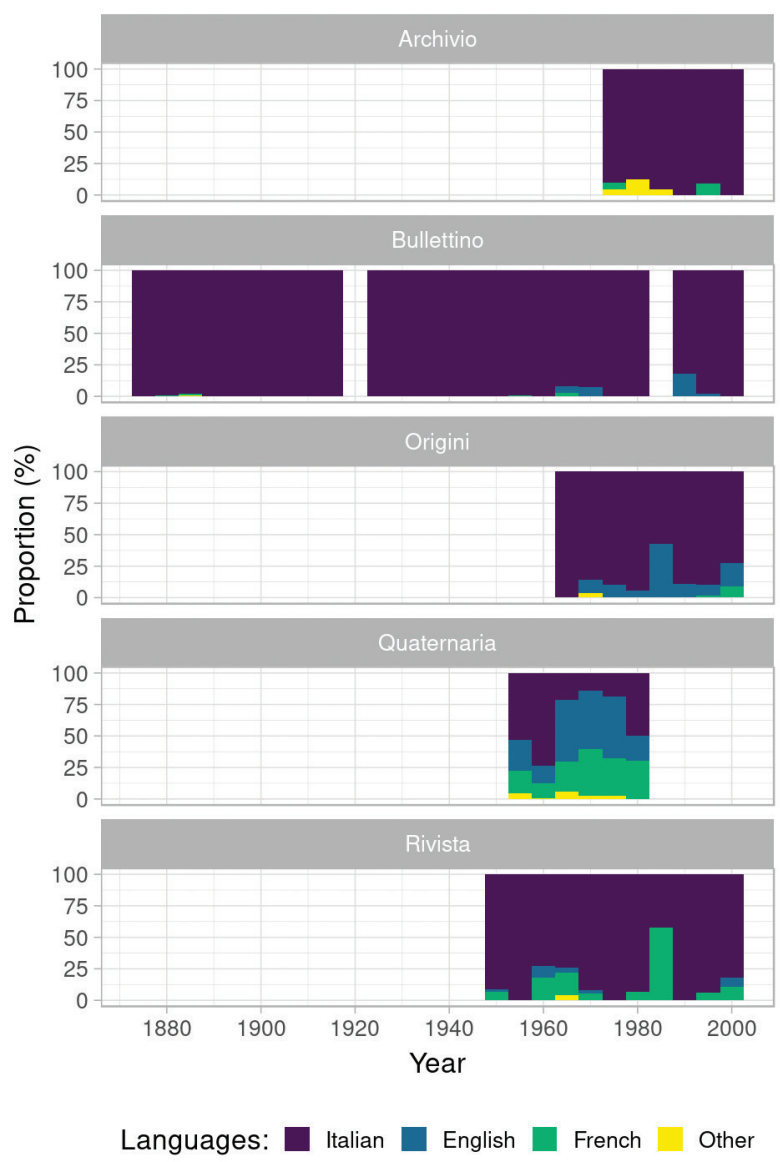

Fig. 3 - Evolution of the proportion of articles, by language and by journal. Each bin covers a period of five years.

S. Plutniak.

into 7 periods delimited by the years the journals started and ended; journals' linguistic and national diversities for each period were assessed using a measure called Rarefaction ${ }^{20}$ (fig. 4). This measure, as well as Shannon-Weaver diversity index, ${ }^{21}$ was also computed by journal without consideration for the time (tab. 4).

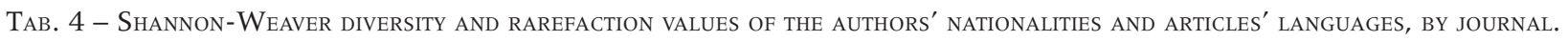

\begin{tabular}{|l|l|l|l|l|}
\hline Journal name & Nationality & & Language & \\
\hline & S.-W. diversity & Rarefaction & S.-W. diversity & Rarefaction \\
\hline Quaternaria & 1.81 & 16.45 & 1.19 & 4.40 \\
\hline RSP & 0.75 & 9.52 & 0.50 & 3.20 \\
\hline Origini & 0.53 & 7.22 & 0.45 & 3.20 \\
\hline ATA & 0.48 & 3.00 & 0.35 & 4.00 \\
\hline BPI & 0.28 & 5.07 & 0.05 & 1.63 \\
\hline
\end{tabular}

20. For an application in bibliometry, see Calver et al. 2010.

21. Contrary to the rarefaction procedure, the ShannonWeaver diversity index does not take into account the potential size effects of the samples. 


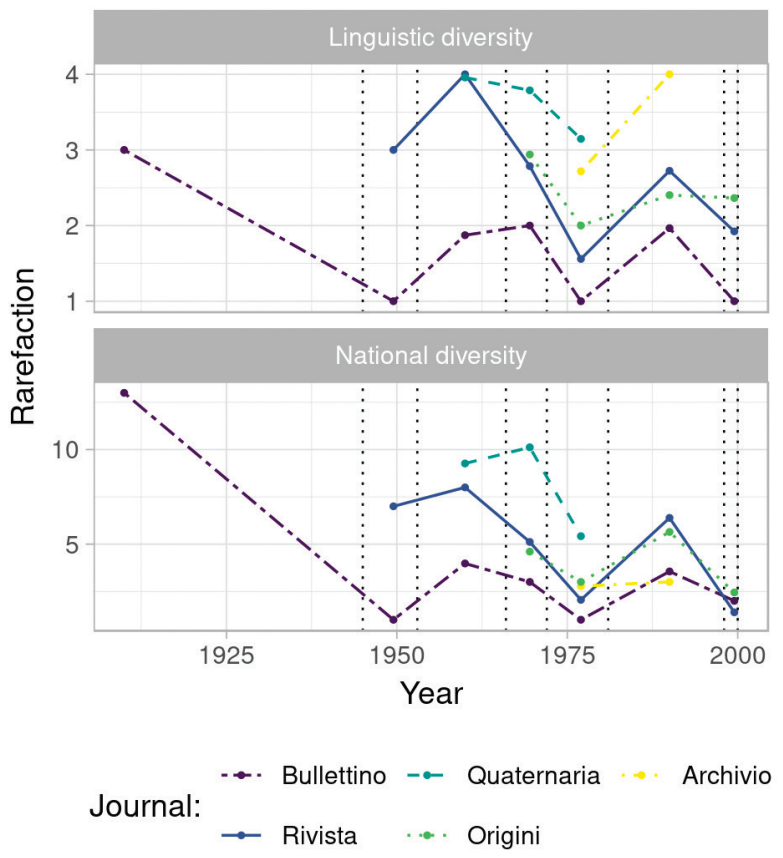

Fig. 4 - Evolution of the national and linguistic diversities (rarefaction values) by journal and by period.

Dashed vertical lines distinguish the 7 periods (the beginning of the first period is not shown). The points are drawn in the middle of their period.

S. Plutniak.

Results showed that, even if some variations are observed at the journal scale, journal rankings were stable for both variable and measure. BPI had the lowest linguistic and national diversities values, and Quaternaria had the highest; RSP had lower and decreasing values during the period when Quaternaria was in publication. ATA had the highest linguistic diversity associated with a rather low national diversity.

In order to detail the journals' characteristics $\chi^{2}$ tests were performed on relevant subsets of tables 2 and 3. For both variables, nationalities and languages, tests led to reject the null hypothesis of independence, and determined significant relationships between the variables (nationality and language) and journals:

1) For nationalities, articles in the BPI had significantly more Italian authors, and fewer French, American and Spanish authors than expected. ${ }^{22}$ Quaternaria had fewer Italian authors, but more French, American, German and British authors than expected. Origini and the RSP had a balanced distribution of authors, but the RSP had more Spanish authors than expected.

2) For languages, similar trends were found. The majority of BPI articles were Italian, whereas Quaternaria had a significantly lower frequency of Italian articles, and higher frequency of English and of French articles than expected, compared to the other journals. In the RSP, the frequency of English articles was significantly below the expected value, whereas Origini had a balanced frequency distribution of languages.

These results clearly show that the journals have different profiles regarding their (inter) national definitions, which result from contrasting editorial policies which may themselves have changed over time.

\section{A typology of journal functions}

In a study of the notion of "national traditions" in the social sciences, Heilbron emphasised that despite normative claims about the universality of science- the scientific international space is historically constructed from national structures. ${ }^{23}$ Scientific journals are important methods used in the process of disciplinarisation and can have different aims. I distinguished three journal functions based on the previous results and consistent observations made of former studies on the growth of prehistoric archaeology in Italy: 1) creating and gathering national publications; 2) supporting a specific research orientation; 3) promoting a local international hub.

The BPI typically fulfilled the first aim and historically has been the only Italian journal devoted to prehistoric archaeology. ${ }^{24}$ After Quaternaria ceased publication, my results have shown that the Italian language and actors dominated in the four other journals. This is consistent with results of other bibliometric studies on archaeology. Kristiansen published a synthesis paper analysing the languages of articles cited in some of the main European prehistoric archaeology journals and in general books published in the last decades of twentieth century (1980-2000). It showed a "European trend towards single language research 
environments" in several countries: e.g. German tends to dominate in German journals, English in British journals. ${ }^{25}$

\section{Supporting a specific orientation}

The growth of prehistoric archaeology in Italy included a double process of intellectual and spatial distinctions; specific approaches to prehistoric archaeology were promoted by different and newly created organisations located in the main cities. Journals were a method to mark and to develop these distinctions. In 1954 a significant conflict arose when the Roman "schools" was opposed by Florence actors who created the Istituto Italiano di Preistoria e Protostoria and a new journal, the RSP, aimed to support new ways to associate historical and natural approaches in prehistoric archaeology. ${ }^{26} \mathrm{~A}$ decade later, when Salvatore M. Puglisi (1912-1985) created the Origini journal at the University of Rome, he also took part in the debate on the general approach in prehistoric archaeology by favouring a historical and anthropological approach. The medium internationalisation scores of Origini (see results) may be related to this focus on the internal Italian debate, although Origini was not closed to foreign influences, as illustrated by the promotion of English approaches by Puglisi. ${ }^{27}$ In contrast, the founder of the RSP, Paolo Graziosi (1906-1988), intended this journal to gather Italian publications in prehistoric archaeology and to strengthen international relations. ${ }^{28}$ However, the RSP, similar to Origini, showed relatively low internationalisation scores. These two journals contrast with the Quaternaria, whose aim was defined as being a "means of international connexion" by A.C. Blanc in the introduction of the first issue.

\section{A local means of internationalisation}

Quaternaria was founded in 1954 by Alberto Carlo Blanc (1906-1960). Son of Gian Alberto Blanc (1879-1966, an internationally renowned geochemist and archaeologist), A.C. Blanc was an important figure in the 1950s. He made strong international commitments, ${ }^{29}$ but became progressively more isolated in the Italian environment. ${ }^{30}$ In 1953, he organised the 4th Congress of the International Union for Quaternary Research (INQUA) in Pisa and Rome. Indeed, Quaternaria was created as an INQUA journal, though edited in Rome and was included in the activities of the Istituto italiano di paleontologia umana. So, likewise Crawford's et al. "locally-grounded transnational research sites", it has been a resource to promote the local (national) growth of prehistoric archaeology in Italy -a country then rather marginal in this field- through a specific commitment to internationalisation.

Similarly, previous bibliometric studies on archaeology emphasised the higher internationality of "small" scientific countries (based on local reception rather than local production, by analysing the cited publications languages). In a case study of the Baltic countries, Lang analysed a set of Estonian, Finnish and Swedish publications (a definition of the data set is not provided, each set is said to be about 4000 items) and showed the high linguistic diversity of their cited works. ${ }^{31}$ In another study, Kristiansen showed that, contrary to Germany or the United Kingdom, smaller countries as Sweden and Hungary had a higher linguistic diversity in their citations in the 19802000 period. ${ }^{32}$

\section{Limitations of the typology: localising the universal}

My results have suggested that journal editors can assign and combine aims at different scales (local, national, international) for their journal. A striking example is illustrated by the ATA.

This very specific publication is closely related to the typologie analytique method, developed from the mid-1950s by French archaeologist Georges Laplace (1918-2004), who conducted a significant part of his first investigations in Italy. ${ }^{33}$ This method integrated a taxonomy, a set of metric coefficients and their relative graphic representa-
25. Kristiansen 2001, p. 40.

26. Tarantini 2004, p. 29-42; Tarantini 2014, p. 369.

27. Guidi 2010 , p. 17.

28. Tarantini 2004, p. 37.
29. Plutniak 2017a, p. 128-130.

30. Tarantini 2004, p. 72-73.

31. Lang 2000.

32. Kristiansen 2001, p. 40.

33. On Laplace in Italy, see Plutniak - Tarantini 2016. 
tions, an articulated set of statistical procedures and a coded notation for the description of prehistoric stone tools. ${ }^{34}$ This method aimed to surpass the numerous locally-defined lithic typologies in various natural languages. However, due to the difficulties encountered by the promoters of this method, work using the typologie analytique were published in non-French conventional journals (especially Italian) ${ }^{35}$ and in the journal of Laplace's research group, ${ }^{36}$ Dialektikê, published by the participants of an annual seminar (1969-1987). Members of the young Italian generation of archaeologists also participated, including Paolo Gambassini. He contributed to diffusing this method, from his position at the University of Siena, by creating the ATA journal in 1973. This journal aimed to publish lists of coded descriptions of lithic objects according to the typologie analytique format. These lists, introduced by a short note written in a natural language, complemented a previous publication in a conventional journal. By their research and teaching, the members of this young generation made the typologie analytique the specific approach of their respective prehistoric archaeology departments, namely in Siena (e.g. P. Gambassini, Annamaria Ronchitelli), Florence (e.g. Fabio Martini, Lucia Sarti) and Ferrara (Alberto Broglio). This distanced themselves from Laplace's research group and with the constant changes and improvements to the method, so promoting a stabilised definition for their group. In some ways, the universal aim of the typologie analytique was turned into a resource that supported local developments. Collaborations between these authors contributed to the differentiation of research trends in Italy, which I will now address by a co-authorship network analysis.

\section{THE GROWTH OF CO-AUTHORSHIP FROM THE $1950 \mathrm{~S}$}

Co-authorship relations can be mathematically represented with graphs ("networks"): two authors are tied if they authored a publication together. Aggregated co-author relations form groups of indirectly grouped authors called

34. See Laplace-Jauretche 1957 and, for an extended presentation, Laplace 1974.

35. Laplace-Jauretche 1957 in Quaternaria.

36. Plutniak 2017b. "connected components": for instance, author A never wrote a publication with author $\mathrm{C}$, but both of them are indirectly tied through their relation to author B with whom they have both written a publication (fig. 5). Depending on the empirical situation, the resulting graph is not necessarily a connected graph (a graph in which there is a path between every pair of vertices): it can be composed of several independent "connected components", which are interpreted as groups of collaborating authors.

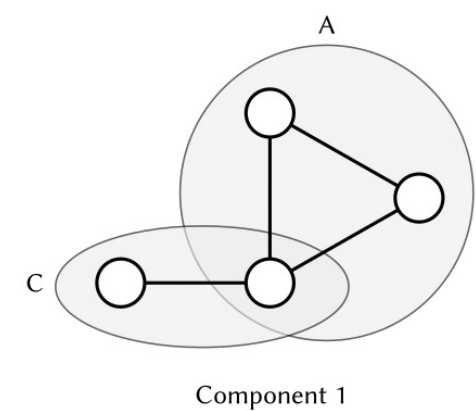

Fig. 5- The component concept.

Co-authorship relationships among 6 authors (white dots) who cosigned 3 publications (A, B, C). This graph has only two connected components.

S. Plutniak.
The following results have been obtained from analysing a series of cumulative annual co-authorship graphs: for each year a graph was computed by summing the relations created in the given year and those of previous years. This mode of construction is justified by the idea that, from an actor's viewpoint, a co-authorship relation can have an influence on his subsequent actions; furthermore, from a bibliographical viewpoint, a co-authorship relation remains indefinitely in the scientific literature (unless the publication is never referenced).

The co-authorship network in the second half of twentieth century

The co-authorship graph is composed of numerous connected components, due to the high number of articles with a single authorship (in 2000, the graph has 668 connected components). Analysing the proportional size of the largest three connected components shows that groups of collab- 
orating authors only began to emerge in the early 1960s (fig. 6). Note that because these graphs are cumulative, a component can only get new relations or stay unchanged between two consecutive years. Contrary to the first component, the second and third components show phases of increase and decrease, always representing less than $5 \%$ of the size of the annual graph for a given year. Increases reflect growth in the groups of connected authors, while decreases are due to their integration in a larger component.

This scenario of the formation of the Italian prehistoric archaeology field, characterised by a progressive increase of collaborations, was confirmed by analysing the transitivity of these relations. Transitivity is a measure of the extent to which authors tend to co-author with the co-authors of their co-authors, so forming triangles. ${ }^{37}$ Resulting values range between 0 (absence of triangles) and 1 (all nodes are part of triangles). Transitivity was computed for each year for

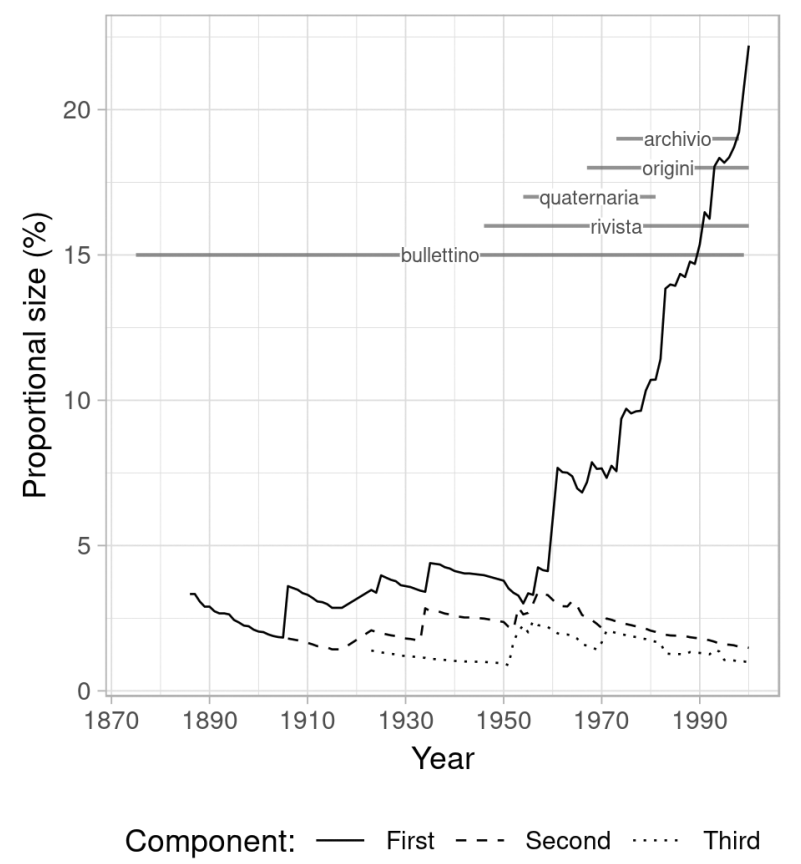

Fig. 6 - Proportional sizes (number of actors) of the first three components in the co-authorship graph.

Horizontal lines indicate the publication period of each journal. S. Plutniak.

37. Most of the definitions of the transitivity rely on the distinction between triplet (set of three connected nodes) and triangle (set of three nodes all connected to each other). Here, transitivity is the number of triangles over the total number of triplets in the graph. the complete graph and for its largest connected component (not the second, third and other components as their nodes change over time).

The interpretation of the evolution of transitivity must acknowledge that these co-authorship graphs are cumulative: an increase in transitivity reflects a new relation between authors who previously haven't worked together. A decrease reflects the arrival of new authors who have not co-authored with the already collaborating authors, or who have collaborated with some of them but not with their previous co-authors.

In the complete graph, the transitivity score shows significant variation until the 1970s when it reaches its highest value of 0.72: after this period the score slowly and steadily decreases (fig. 7). This reflects a slight degree of collaboration with the newcomers in the field, even if -as already stated- their numbers still increase during the period (see fig. 1).

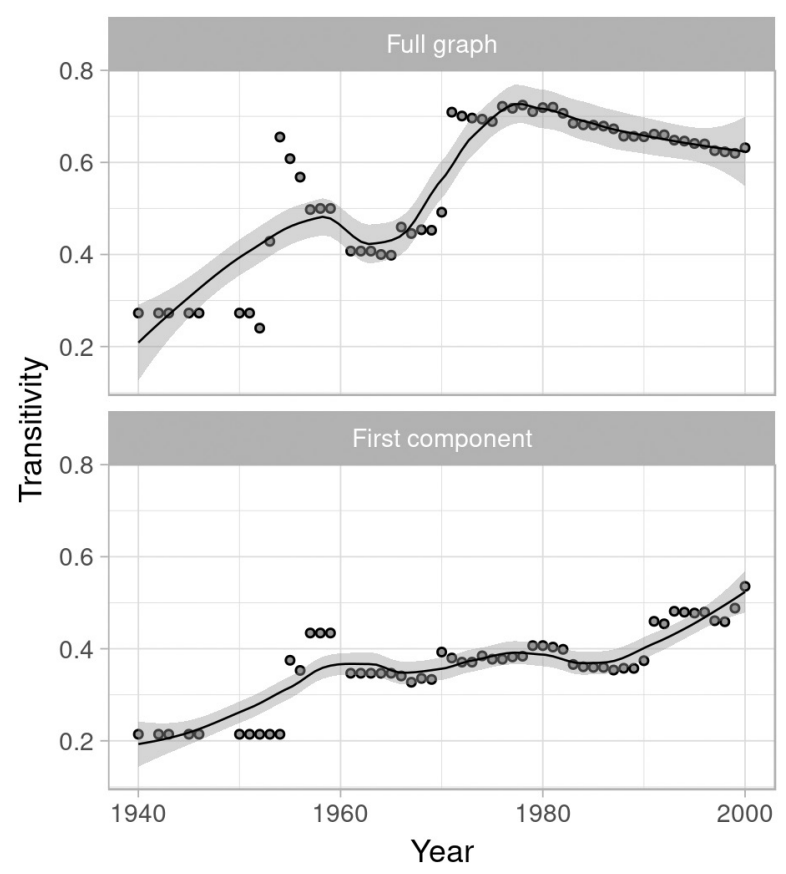

Fig. 7 - Evolution of the average transitivity in the annual graph and in the largest component.

The curves and their confidence intervals are obtained by Loess local regression fitting.

S. Plutniak. 
Fluctuations of transitivity in the largest component are less significant and globally increase over the period, reaching its highest value of 0.53 in the final year (2000). This confirms the previous observation: the collaboration network has a centre-periphery structure.

Statistical evaluations of the observed transitivity values computed for the year 2000 show that the observed values are significantly higher than expected (for the annual graph and for its largest connected component). ${ }^{38}$ This supports the idea that the structural property of the co-authorship network is related to some particularities of the authorship practises in the field of prehistoric archaeology.

\section{Emergence of leading actors}

For a detailed analysis of the structure of the network, centrality measurements were also computed at the scale of the author. The betweenness centrality value of each actor and the betweenness centralization value for each annual graph were computed (see definitions in fig. 8).

The increase in global betweenness centralization from the mid-1950s suggests a distinction process in the co-authorship network (fig. 9). The network tends to be composed of an increasing number of dense sub-networks: different phyla ("traditions") of collaborators are progressively being formed. At the scale of the actors, two groups appear: Italian actors, characterised by an increasing betweenness centrality during the period; and non-Italian actors, with decreasing values. This reflects the ongoing structuration of prehistoric archaeology in Italy from 1950 to 2000: prominent figures emerged who led their own research groups (or "traditions") and occupied relevant intermediate positions (e.g. A.C. Blanc, F. Martini, and A. Broglio). The decrease in betweenness centrality of foreign authors is interpreted as reflecting their specific attachment to some of these groups. Laplace is the only exception as he kept an important intermediate position, despite not being Italian.

38. Cug test procedures (Univariate Conditional Uniform Graph) have been used, which compare the observed value with those computed on similar randomly generated graphs. See supplementary materials.

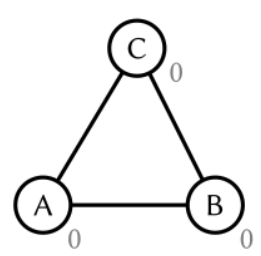

Centralization: 0

(a)

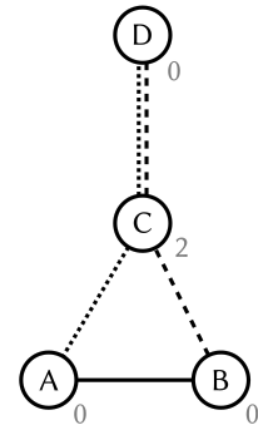

Centralization: 0.67

(b)
Fig. 8 - Definition of betweenness centrality and betweenness centralization.

With Node betweenness centrality the shortest paths a node is part of, which connect other nodes in the graph, the more it is considered as central in the graph (higher betweenness centrality). In (a) all the nodes are found at an equal distance from each other, so their betweenness centrality scores (in grey) are null. In (b) node $C$ is part of two shortest paths (from $A$ to $D$ and from $B$ to $D$ ), so $C$ has a non-null betweenness centrality score. Betweenness centralization is a graph-level measure summarising the centrality scores of the nodes and reflecting the extent in which a graph is structured around some specific central nodes (Freeman 1979). S. Plutniak.

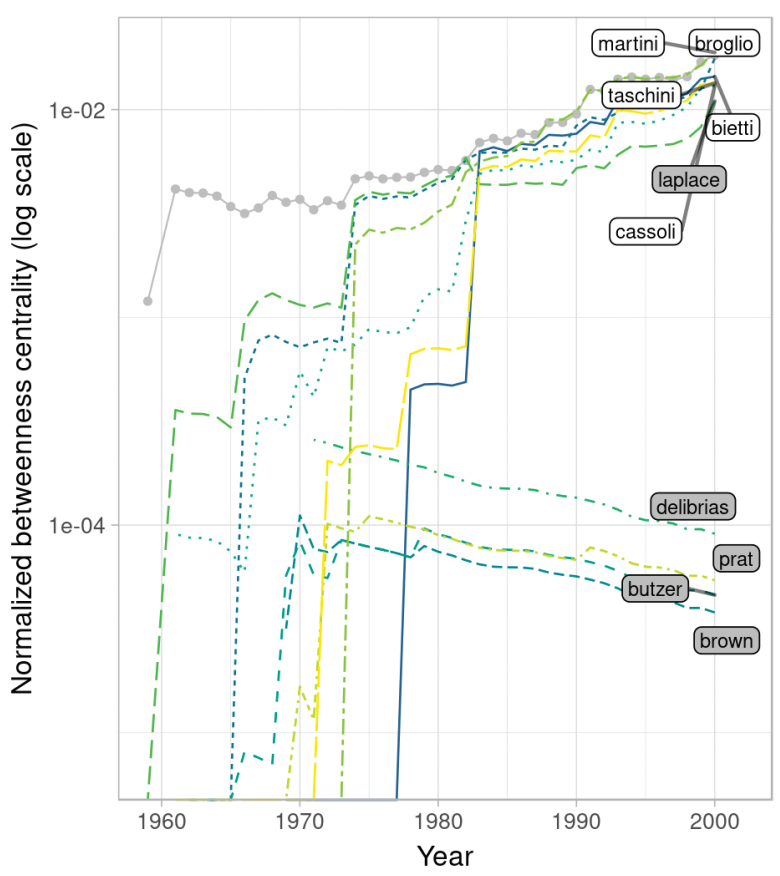

Fig. 9 - Authors' centrality over time.

Author betweenness centralities in annual series of cumulated co-authorship graphs and betweenness centralization (grey dots and line). Italian authors (white labels) and not-Italian authors (grey labels) (only the five highest betweenness centrality scores for both are displayed). Y-axis has a logarithmic scale.

S. Plutniak. 


\section{National differentiation in the co-authorship network}

In total, there are 42 authors nationalities in the data set. Their distributions in the first three components of the co-authorship series are discussed. Even if the relations are cumulated over time in the co-authorship graph, the sets of actors related to the first, the second, the third and the following component size ranks can change. Changes in the proportional size (in terms of relation counts) show when this happened; for instance, in the early 1950s, the second component, which was composed of German, Dutch and Italian authors, was replaced by a group of Italian authors (fig. 10).

The main observation is that the structure of the main part of the co-authorship network was highly variable until the early 1970s. Afterwards,
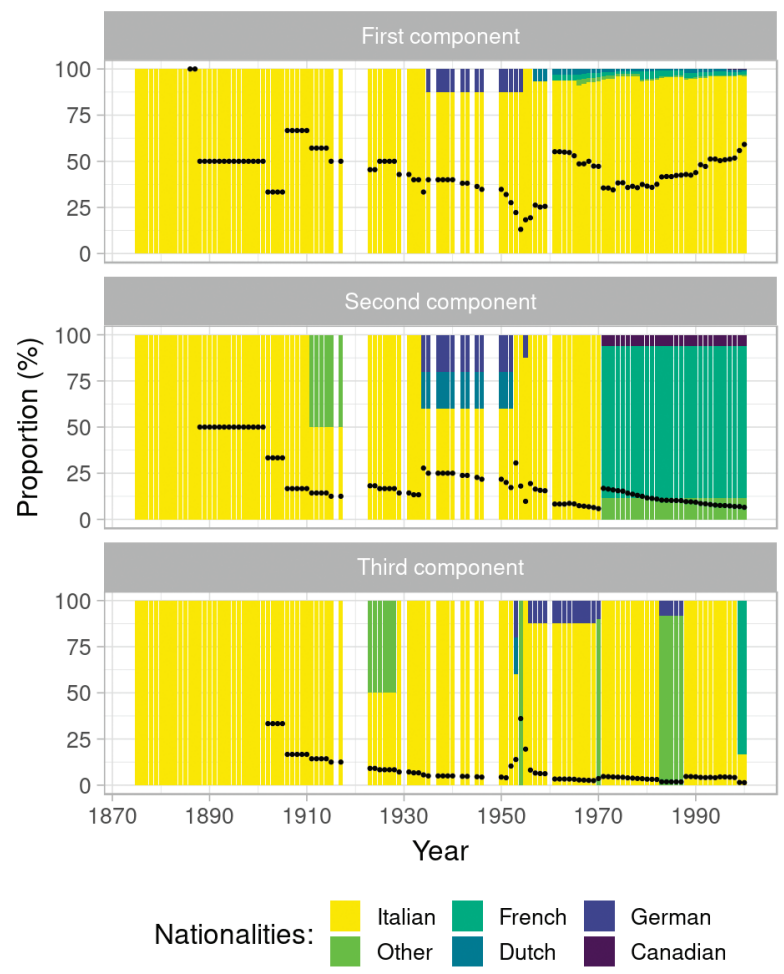

Fig. 10 - Proportion of nationalities in the main three components of the co-authorship graph.

For each year and each component, the black dot gives the proportional size (in terms of relation counts) of the given component in the full co-authorship graph.

S. Plutniak. it stabilised with an Italian-dominated giant first component and a smaller second component dominated by French-British actors. The third component continued to change over the 19702000 period. Note the decreasing importance of German actors over the complete period, passing from the first to the second and, in the mid-1950s, to the third component.

The general relations pattern between authors of different nationalities were studied by the assortative mixing of the network, which is defined as the "tendency for vertices in networks to be connected to other vertices that are like (or unlike) them in some way". ${ }^{39}$ In this co-authorship network, it evaluates the extent to which actors sharing the same nationality tend to have more relationships. A negative value means that authors of the same nationality tend not to collaborate and a positive value means, to the contrary, that they significantly tend to co-author articles together. Results suggest a decrease in the preferential relations between actors of the same nationality, from the mid-1950s to 1980 (fig. 11). This corresponds to the period when Quaternaria was published. An increase in national preference is then observed, followed by a decrease in preference from the late 1980s to 2000.

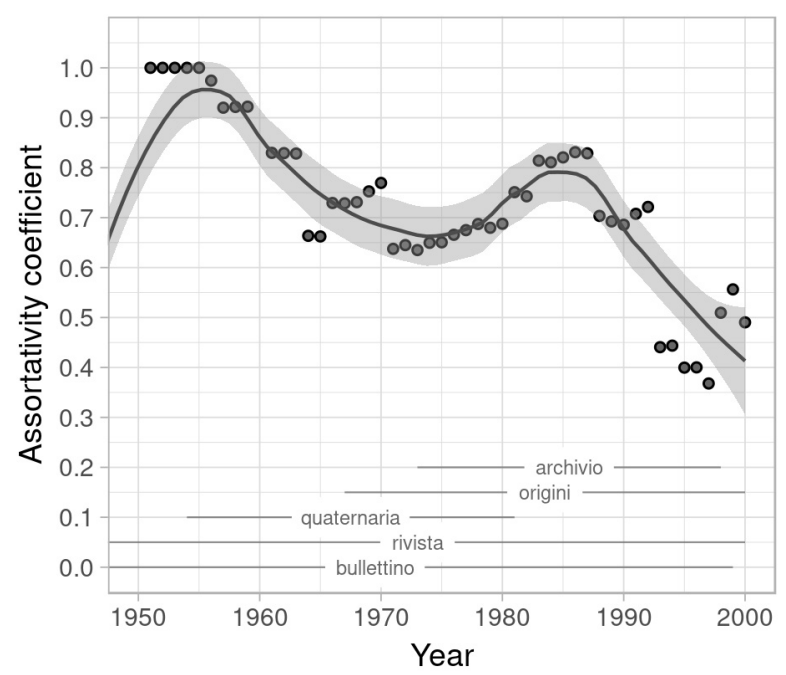

Fig. 11 - Relations between authors of the same nationality. National assortativity coefficient in the annual graphs of cumulative co-authorship relations (with a smoothing mobile window of 10 years) and publication period of each journal. The curve and its confidence interval are obtained by Loess local regression fitting.

S. Plutniak. 
CONCLUSION: THE HISTORICAL VALUE OF BIBLIOMETRIC APPROACHES

This case study aimed to address some classic concepts of bibliometric analyses -such as the transition from national to transnational science- by examining a scientific discipline, language and time period poorly represented in bibliographic databases used in bibliometric studies. Zitt et al. characterised this transition by the appearance of three features in scientific productions: indexed journals (in main bibliographic databases), prominence of the English language, and concentration in high impact journals. ${ }^{40}$ Although my data cannot test these three aspects, results suggest that a transition to a transnational model of science did not occur during the study period.

However, results reflect the structuration and aggregation of a cognitive and social network at the national scale, different editorial strategies and the growth of research trends. A key-finding is that the most important change did not concern internationalisation, but a change in the social organisation of prehistoric archaeology production, namely the emergence of co-authorship from the 1950s. Collaboration is a necessary, but a non-sufficient condition, for international publications, and internationality is merely one of a number of resources. To summarise, three phases were distinguished: a slight international opening; a moderate increase in internationalisation (either by importing foreign work or by setting up local international hubs); and an increase in internationalisation by the exportation of local resources (assumed but not observed with these data), according to the shift to Zitt's et al. definition of transnational science.

Scientific internationalism is a historic issue in scientific practise, but it is even more important today for two main reasons. First, it is an important characteristic of the scientific ethical dimension of science. Joseph Schumpeter's 1931 norma- tive claim that "Science is of no country and does not bear any homogeneous national traits" ${ }^{41}$ illustrated this, as well as its embedding in the norm of universalism by Robert Merton in his classical definition of the scientific ethos. Second, in recent years, internationality has become one of the main parameters for the evaluation and policy setting of scientific activities. As a consequence, its economic and political dimensions have become more important, so complementing its ethical aspect. Ethical and political aspects of internationality have reciprocal effects, challenging analysts of scientific internationality with two types of risk. An epistemological risk: the importance of internationality as an aspect of the scientific ethos can lead to ideologically (over-)emphasise the international features of the scientific practises studied. A methodological and political risk: being an important parameter for science policies, the needs of a management-oriented perspective on internationality can lead to inflating a (quantified) and restrictive definition of the concept, with feedback effects on the scientific ethos.

However, none of these risks justify abandoning the study of internationality in science or the quantified attempts to perform such studies. Intermediate approaches and methodology, combining bibliometric and qualitative data have been recently advocated, ${ }^{42}$ and this case study of Italian prehistoric archaeology is intended to contribute to such an approach. As demonstrated by the identification of Laplace's particular position in the co-authorship network, the use of a large data set and quantified procedures can capture fine-grained biographical facts. Future analysis of this data set will use measurement methods of internationality at the article-scale, not the journal scale. This analysis of local production could be complemented by analysing Italian publications in non-Italian journals, and the internationality of the reception of prehistoric archaeology in Italy. 


\section{Bibliography}

Archambault et al. 2006 = É. Archambault et al., Benchmarking scientific output in the social sciences and humanities: the limits of existing databases, in Scientometrics, 68-3, 2006, p. 329-342.

Buela-Casal et al. 2006 = G. Buela-Casal et al., Measuring internationality: reflections and perspectives on academic journals, in Scientometrics, 67-1, 2006, p. 45-65.

Calver et al. $2010=$ M. Calver et al., What makes a journal international? A case study using conservation biology journals, in Scientometrics, 85-2, 2010, p. 387-400.

Crawford - Shinn - Sörlin 1993 = E. Crawford, T. Shinn, S. Sörlin, The nationalisation and denationalization of the science, in Id. (ed.), Denationalizing science: the contexts of international scientific practice, Dordrecht, 1993, p. 1-42.

Delley et al. 2016 = G. Delley et al. (ed.), History of archaeology: international perspectives, Oxford, 2016.

De Solla Price 1963 = D.J. De Solla Price, Little science, big science, New York, 1963.

Díaz-Andreu 2014 = M. Díaz-Andreu, Transnationalism and archaeology. The connecting origins of the main institutions dealing with prehistoric archaeology in western Europe: the IPH, the CIPP and the CRPU (1910-1914), in A. Guidi (ed.), 150 anni di preistoria e protostoria in Italia, Florence, 2014, p. 163-177.

Elzinga - Landström 1996 = A. Elzinga, C. Landström, Internationalism and science, London, 1996.

Forman $1971=$ P. Forman, Weimar culture, causality, and quantum theory, 1918-1927: adaptation by German physicists and mathematicians to a hostile intellectual environment, in Historical Studies in the Physical Sciences, 3, 1971, p. 1-115.

Freeman 1979 = L.C. Freeman, Centrality in social networks: conceptual clarification, in Social Networks, 1, 1979, p. 215-239.

Garfield - Sher - Torpie 1964 = E. Garfield, I.H. Sher, R.J. Torpie, The use of citation data in writing the history of science, AF 49(638)-1256, Air Force Office of Scientific Research, Philadelphia, 1964.

Gingras 1991 = Y. Gingras, L'institutionnalisation de la recherche en milieu universitaire et ses effets, in Sociologie et sociétés, 23-1, 1991, p. 41-54.

Gingras $2010=Y$. Gingras, Mapping the structure of the intellectual field using citation and co-citation analysis of correspondences, in History of European Ideas, 36-3, 2010, p. 330-339.

Gingras $2014=$ Y. Gingras, Les dérives de l'évaluation de la recherche. Du bon usage de la bibliométrie, Paris, 2014.

Guidi 2010 = A. Guidi, The historical development of Italian prehistoric archaeology: a brief outline, in Bulletin of the History of Archaeology, 20-2, 2010, p. 13-20.

Heilbron 2008 = J. Heilbron, Qu'est-ce qu'une tradition nationale en sciences sociales?, in Revue d'histoire des sciences humaines, 18-1, 2008, p. 3-16.

Kaeser $2002=$ M.-A. Kaeser, On the international roots of prehistory, in Antiquity, 76-291, 2002, p. 170-177.
Kristiansen 2001 = K. Kristiansen, Borders of ignorance: $r$ search communities and language, in Z. Kobyliński (ed.), Quo vadis archaeologia? Whither European archaeology in the $21^{\text {st }}$ century?, Warsaw, 2001, p. 38-44.

Lang $2000=$ V. Lang, Archaeology and language, in Fennoscandia Archaeologica, 17, 2000, p. 103-111.

Laplace 1974 = G. Laplace, La typologie analytique et structurale: base rationnelle d'étude des industries lithiques et osseuses, in M. Borillo, J.-C. Gardin (ed.), Les banques de données archéologiques, Paris, 1974, p. 91-143.

Laplace-Jauretche 1957 = G. Laplace-Jauretche, Typologie analytique. Application d'une nouvelle méthode d'étude des formes et des structures aux industries à lames et lamelles, in Quaternaria, 4, 1957, p. 133-164.

Newman 2003 = M.E.J. Newman, Mixing patterns in networks, in Physical Review E, 67-2, 2003, p. 026126.

Plutniak 2017a = S. Plutniak, L'innovation méthodologique, entre bifurcation personnelle et formation des disciplines: les entrées en archéologie de Georges Laplace et de Jean-Claude Gardin, in Revue d'histoire des sciences humaines, 31, 2017, p. 113-139, HDL: 10670/1.rw3o20.

Plutniak $2017 \mathrm{~b}=\mathrm{S}$. Plutniak, The professionalisation of science - claim and refusal: discipline building and ideals of scientific autonomy in the growth of prehistoric archaeology. The case of Georges Laplace's group of Typologie analytique, 1950s-1990s, in Organon, 49, 2017, p. 105-154, HDL: 10670/1.y5rnm6.

Plutniak 2018 = S. Plutniak, The growth of prehistoric archaeology in Italy (1875-2016), Harvard Dataverse, DOI: 10.7910/DVN/WCNF50.

Plutniak - Tarantini 2016 = S. Plutniak, M. Tarantini, An influential outsider. Georges Laplace between French institutions and Italian prehistory, in Delley et al. 2016, p. 79-89.

Somsen 2008 = G.J. Somsen, A history of universalism: conceptions of the internationality of science from the enlightenment to the Cold War, in Minerva, 46-3, 2008, p. 361-379.

Tarantini 2002 = M. Tarantini, Appunti sui rapporti tra archeologia preistorica e fascismo, in Origini, 24, 2002, p. 7-65.

Tarantini $2004=$ M. Tarantini, Dal fascismo alla repubblica. La fondazione dell'Istituto Italiano di Preistoria e Protostoria nel quadro della ricerca (1927-1960), in Rivista di scienze preistoriche, 54, 2004, p. 5-82.

Tarantini 2014 = M. Tarantini, Continuità, rinnovamenti, contaminazioni. Preistoria e protostoria in Italia dal 1925 al 1962, in A. Guidi (ed.), 150 anni di preistoria e protostoria in Italia, Florence, 2014, p. 363-372.

Zitt - Perrot - Barré 1998 = M. Zitt, F. Perrot, R. Barré, The transition from "national" to "transnational" model and related measures of countries' performance, in Journal of the American Society for Information Science, 49-1, 1998, p. 30-42. 